Таким образом, кредитные организации, основной сферой деятельности которых являются операции с денежными средствами, часто становятся объектом воздействия со стороны криминальных групп и отдельных личностей, которые с помощью денежных переводов и другими способами пытаются легализовать средства, полученные преступным путем.

Банки обладают широкими возможностями для выявления подозрительных операций. Поэтому осуществляя свою деятельность в сфере противодействия легализации (отмыванию) доходов, полученных преступным путем, и финансирования терроризма, они выполняют основные и специальные обязанности, реализуя свои основные функции - выявление и направление в Росфинмониторинг и другие государственные надзорные органы сведения об операциях, подлежащих обязательному контролю и сомнительных операций.

Помимо вышеназванных функций Банк России продолжает проводить нормативнометодологическую работу в области ПОД/ФТ, разрабатывая и издавая соответствующие положения, указания и письма, регулирующие исполнение кредитными организациями требования антилегализационного законодательства.

1. Иванов, А.В. Предотвращение финансового мошенничества в целях противодействия легализации преступных доходов / А.В. Иванов // Управленческий учет. - 2016. —№2. —C. 86-93.

2. Лебедева, А.А Противодействие использованию банковской системы в целях легализации доходов, полученных преступным путем / А.А. Лебедева // Безопасность бизнеса. 2014. — № 3. - С. 37-40.

3. Об открытии банковских счетов и аккредитивов, о заключении договоров банковского вклада хозяйственными обществами, имеющими стратегическое значение для оборонно-промышленного комплекса и безопасности Российской Федерации, и внесении изменений в отдельные законодательные акты Российской Федерации: Федеральный закон от 21 июля 2014 г. № 213-Ф3 (в ред. от 27.12.2019) // Собрание законодательства РФ. - 2014. — №30. - ст.4214.

4. Шохин, С.О. Проблемы правового обеспечения борьбы с легализацией незаконно полученных доходов в Евразийском экономическом союзе // Юрист. — 2018. —№1. — С. 53.

\title{
Земсков И.Н. \\ Генезис уголовной ответственности за побег из места лишения свободы, из-под ареста или из-под стражи в России
}

Владимирский юридический институт Федеральной службы исполнения наказаний (Россия, Владимир)

doi: 10.18411/trnio-11-2021-240

\section{Аннотация}

Статья посвящена истории развития института уголовной ответственности за побег из места лишения свободы, из-под ареста или из-под стражи в России. Автором проводится анализ нормативных правовых актов, отражающих уголовную ответственность за побег из мест заключения и принудительной изоляции в период с 1845 года по настоящее время. В ходе анализа нормативной базы дореволюционной России, советского государства и современной России автор дает вывод, что история развития института уголовной ответственности за побег позволяет выделить три этапа развития.

Ключевые слова: побег из-под стражи, из мест заключения, уголовная ответственность, история развития, принудительная изоляция, колонии-поселения, исправительно-трудовой лагерь.

\section{Abstract}

The article is devoted to the history of the development of the institution of criminal responsibility for escape from a place of imprisonment, from arrest or from custody in Russia. The author analyzes the normative legal acts reflecting the criminal responsibility for escape from places of detention and forced isolation in the period from 1845 to the present. In the course of analyzing 
the regulatory framework of pre-revolutionary Russia, the Soviet state and modern Russia, the author concludes that the history of the development of the institution of criminal responsibility for escape makes it possible to distinguish three stages of development.

Keywords: escape from custody, from places of detention, criminal responsibility, history of development, forced isolation, settlement colonies, forced labor camp.

История развития уголовной ответственности за побег из мест лишения свободы совершенствовалось на протяжении многих десятилетий.

Многие авторы считают началом возникновения уголовной ответственности за побег с XIII в. - 1845 г. На наш взгляд, данное мнение является ошибочным, поскольку до 1845 года уголовная ответственность лица, совершившего побег, не была отражена ни в одном правовом акте того времени, а лишь была предусмотрена ответственность для лиц (например, приставы), обеспечивающих исполнение наказания или меру пресечения.

В связи с вышеизложенным считаем возможным связать начальный этап возникновения уголовной ответственности за побег из мест лишения свободы с принятием в 1845 г. Уложения о наказаниях уголовных и исправительных (далее - Уложение 1845 года).

До начала революций в царской России ответственность за совершение побега из мест лишения свободы была предусмотрена в разделе 4 Уложения 1845 года «О преступлениях и проступках против порядка управления», а именно в статье 309 , которая включала в себя ответственность не только за совершение самого побега, но и за оказание содействия в его совершении другими лицами. Данная статья состояла из нескольких частей: первая и вторая предусматривали квалифицирующие признаки совершения побега, а третья за совершение побега без отягчающих обстоятельств.

В Уголовном уложении Российской Империи 1903 г. было сформировано несколько составов преступлений, касающихся побега: побег из мест лишения свободы, побег с поселения (ст. 175) и побег с каторги (ст. 176) [1]. Данные составы были включены в главу «О противодействии правосудию».

После образования в России советской власти все царское законодательство было отменено. Данный факт позволяет выделить нам начальный этап становления уголовной ответственности за совершение побега из мест принудительной изоляции (1845-1917 гг.).

Впервые за всю историю советская власть путем принятия в 1918 году Временной инструкции «О лишении свободы как мере наказания, и о порядке отбывания такового» определила порядок отбывания наказания в виде лишения свободы.

15.04.1919 постановлением ВЦИК «О лагерях принудительных работ» было установлено, что все лагеря передаются в ведение соответствующих исполкомов, а общее управление всеми лагерями возлагалось на НКВД.

Данное постановление предусматривало уголовную ответственность за побег из мест лишения свободы, которая была достаточно сурова. Лицу, совершившему побег впервые, срок отбывания наказания мог быть увеличен в 10 раз, а за вновь совершенный побег осужденного могли приговорить к высшей мере наказания через суд Революционного трибунала. Законодатель выделил два места совершения преступления: лагеря и места работы, а субъектами рассматриваемого преступления были лица, отбывающие наказание в виде лишения свободы [3]. На наш взгляд, такие кардинальные меры были необходимы на рассматриваемом этапе, поскольку революция и гражданская война дестабилизировали обстановку в стране, чем и воспользовался преступный сегмент, а государство это пресекло введением жестких и беспринципиальных норм уголовного права.

После принятия в 1922 УК РСФСР уголовная ответственность за побег была отнесена к преступлениям против порядка управления. Следует отметить, что уголовная ответственность за совершение побега наступала при сопряжении данного деяния с повреждением целостности конструкций мест изоляции, а именно посредством подкопа, взлома, повреждения затворов или стен. При отсутствии в совершенном побеге указанных выше признаков, лицо привлекали не к уголовной, а к дисциплинарной ответственности. 
Помимо этого была предусмотрена уголовная ответственность за освобождение арестованного из-под стражи или из мест принудительной изоляции.

Постановлением Всероссийского центрального исполнительного комитета в 1924 году уголовная ответственность за побег из мест заключения или из-под стражи была исключена и определялась Исправительно-трудовым кодексом РСФСР 1924 года, как дисциплинарная, за исключением совершения побега, сопряженного со взломом, подкопом или насилием. Помимо этого время, проведенное вне места заключения, с момента побега до возвращения, в срок лишения свободы не засчитывалось.

После введения 22 ноября 1926 года нового УК РСФСР уголовная ответственность за побег была возвращена, а суть данной нормы была схожа с нормой, содержащейся в УК РСФСР 1922 года. Необходимость вернуть уголовную ответственность за побег возникла в связи с увеличением количества, кроме того, отмена уголовной ответственности за побег ослабила работу правоохранительных органов по их предупреждению.

Период 30-50-х гг. ХХ в. характеризуется репрессивной политикой И.В. Сталина, что повлияло на ужесточение уголовной ответственности за многие преступления, в число которых входил побег. Был увеличен срок отбывания наказания за совершение данного деяния, а помимо этого в ряде случаев назначалась смертная казнь за совершение побега.

Следует отметить, что, несмотря на Постановление ЦИК СССР, практика ответственности за побег была неоднозначной. В ряде исправительных колоний за побег предшествовало наказание в виде помещения в штрафной изолятор. Соответственно, лица привлекались не к уголовной, а к дисциплинарной ответственности.

До принятия УК РСФСР 1960 г. уголовное законодательство, предусматривающее ответственность за побеги не менялось. УК РСФСР 1960 г. не содержал в себе дифференцированного подхода при оценке общественной опасности побега, поскольку существовал только единственный квалифицированный состав - совершение побега, сопряженное с насилием над стражей.

Ответственность за побег в УК РСФСР 1960 г. предусматривалась статьей 188, которая гласила: «Побег из места заключения или из-под стражи, совершенный лицом, отбывающим наказание или находящимся в предварительном заключении». Кроме того, законодатель выделил два самостоятельных состава преступления за различные виды побега: побег из места ссылки (ст.186 УК) и самовольное возвращение в места, запрещенные для проживания (ст.187 УК), что имело положительное значение для развития института уголовной ответственности за совершение побега, т.к. была произведена дифференцирация уголовно-правовых норм, касающихся борьбы с побегами.

Стоит отметить, что по УК РСФСР 1960 г., в отличие от предшествующего уголовного законодательства, лица, оказавшие содействие в совершении побега, несли уголовную ответственность за соучастие. Так же уголовная ответственность была предусмотрена за укрывательство ряда преступлений, в число которых входил побег из места заключения или из-под стражи. Должностные лица, оказавшие содействие в совершении побега с использование своего служебного положения, несли ответственность за должностные преступления.

Необходимо подчеркнуть, что Указом Президиума Верховного Совета РСФСР от 11 марта 1977 г. была введена норма, предусматривающая уголовную ответственность за уклонение от отбывания наказания в виде лишения свободы. Данная норма позволяла разграничивать побег и уклонение.

В 1963 г. в систему исправительных учреждений были введены колонии-поселения, а в 1977 - колонии-поселения для лиц, совершивших преступления по неосторожности. В связи с этим законодатель счел необходимым ввести норму, предусматривающую уголовную ответственность за уклонение от отбывания наказания в виде лишения свободы. Поскольку в колониях-поселениях содержались лица, не представляющие большой общественной опасности для общества, то необходимости в строгой изоляции данных лиц не было и было вполне достаточным нахождение их не под охраной, а под надзором. По мнению ученых того времени, пересечение границ колоний-поселений лицами, там содержащимися, не представляло большой общественной опасности. 
В 1993 году в УК РСФСР 1960 г. были внесены большие изменения в части, касающейся побега. Норма, предусматривающая ответственность за побег, была дополнена квалифицирующими признаками, такими как: побег, совершенный с применением насилия либо способом, создающим угрозу для жизни или здоровья других лиц; повторность; совершение побега по предварительному сговору группой лиц; с повреждением инженернотехнических средств охраны или путем подкопа; с завладением оружием или его использованием.

Нужно согласиться с мнением О. В. Мазура, обозначившего, что увеличение количества квалифицирующих признаков побега позволило разделить уголовную ответственность за это деяние в зависимости от обстоятельств объективной стороны преступления, что послужило положительным опытом в плане борьбы с побегами [1].

Изучая советский период развития уголовной ответственности за побег (1917-1996 гг.), следует отметить кардинальные изменения данного состава, а также тенденцию на ужесточение уголовной ответственности за совершение указанного деяния.

Если охарактеризовать современный этап развития уголовной ответственности за побег, необходимо добавить, что основные признаки побега были сохранены законодателем в статье 313 УК РФ 1996 года.

Подчеркнем, что в последнее время наметилась тенденция на либерализацию уголовной ответственности за побег.

Так, первый заместитель директора ФСИН России А.А. Рудый в 2013 году выступил за декриминализацию побега из колоний-поселений. При этом им было отмечено, что действующая норма ст. 313 УК РФ не дифференцирует уголовную ответственность за побег в зависимости от вида оставленного исправительного учреждения, при этом побег из колоний-поселений не представляет такой общественной опасности как то же деяние, совершенное из других исправительных учреждений, и за его совершение вполне можно ограничиться применением мер административного характера - перевод данного правонарушения в разряд злостных нарушений установленного порядка отбывания наказания. Таким образом, мы видим, что институт уголовной ответственности за совершение побега из места лишения свободы из-под стражи или ареста является довольно динамично развивающимся институтом уголовного права[2].

Обобщив вышеизложенное, отметим, что история развития института уголовной ответственности за побег позволяет выделить три этапа:

1 этап - этап становления уголовной ответственности для лиц, совершивших побег $(1845-1917$ гг.).

2 этап - советский (1917 - 1996 гг.), характеризующийся развитием правового регулирования уголовной ответственности за совершение побега, с учетом развития системы органов уголовно-исполнительной системы. Данный этап отличается уверенной тенденцией на ужесточение уголовной ответственности за совершение указанного деяния и наличием нескольких норм, предусматривающих различные виды побегов в зависимости от места совершения.

3 этап - современный (1996 г. - н.в.), характеризуется объединением всех видов побегов в рамках единой нормы (ст. 313 УК РФ) и наличием тенденции к снижению побегов из колоний-поселений.

$$
* * *
$$

1. Мазур 1997 - Мазур О. В. Уголовно-правовые и криминологические проблемы борьбы с побегами из мест лишения свободы : специальность 12.00.08 «Уголовное право и криминология; уголовно-исполнительное право» : автореферат диссертации на соискание ученой степени кандидата юридических наук / Мазур Олег Васильевич. - Омск, 1997. - 22 с.

2. ФСИН предложила отменить уголовную ответственность за побег из колоний- поселений: статья [электронный ресурс] // Правда.ру - информ. портал. URL: https://www.pravda.ru/news/society/1205020-fsin/ (дата обращения: 20.09.2021).

3. Собрание узаконений и распоряжений рабочего и крестьянского правительства РСФСР (далее СУ РСФСР). 1919. № 53, ст. 589. 